\title{
PERSPEKTIF HUKUM PIDANA DAN \\ KRIMINOLOGI TERHADAP TINDAK PIDANA \\ PENANGKAPAN IKAN SECARA ILEGAL (ILLEGAL FISHING) DI INDONESIA
}

\author{
Wigit Adi Sasminto \\ Pusdik Brimob Watukosek \\ Email : awigit94@gmail.com
}

\begin{abstract}
Abstrak
Salah satu kekayaan alam dari bangsa indonesia adalah sumber daya alam dari bumi laut indonesia mulai dari indahnya terumbu karang hingga jutaan bahkan milyaran ikan yang bersemayam dalam bumi laut indonesia. Namun demikian kekayaan yang berlimpah dari sumber daya alam tersebut tidak lantas menjadikan masyarakat indonesia secara umum berada dalam kondisi sejahtera dan dapat menikmati kekayaan tersebut. Hal ini terjadi karena beberapa hal salah satu di antaranya adalah maraknya praktek tindak pidana pencurian ikan atau yang dikenal dengan istilah illegal fhising. Sebagai wujud dan komitmen Negara dalam melindungi ekosistm laut (Ikan), pemerintah merevisi Undang-Undang Nomor 31 Tahun 2004 menjadi Undang-Undang Nomor 45 Tahun 2009 Tentang Perikanan dengan tujuan lahirnya Undang-undang ini dapat meminimalisir dan sekaligus mencegah terjadinya illegal fishing dan para pelaku dapat dijerat dengan pidana sesuai dengan ketentuan peraturan perundang-undangan yang berlaku.
\end{abstract}

Kata kunci: Hukum Pidana, Kriminologi, Penangkapan Ikan

\begin{abstract}
One of the natural resources of the Indonesian nation is the natural resources of the Indonesian sea, ranging from the beauty of coral reefs to millions and even billions of fish that reside in the Indonesian sea. However, the general recognition of these natural resources does not necessarily mean that the Indonesian people are in a prosperous condition and can enjoy this wealth. This happens because of several things, one of which is the practice of the criminal act of robbery of fish or what is known as illegal. As a manifestation and commitment of the State in protecting marine ecosystems (fish), the government has revised Law Number 31 of 2004 into Law Number 45 of 2009 concerning Fisheries with the aim of this Law being able to minimize and simultaneously prevent the implementation of illegal fishing and fisheries. perpetrator Can be charged with a crime in accordance with the provisions of the proper statutory.
\end{abstract}

Keywords: Criminal Law, Criminology, Illegal Fishing,

\section{PENDAHULUAN}

Sebagai wujud dan komitmen pemerintah dalam mempertahakan ekosistem alam dalam hal ini adalah kekayaan laut Indonesia yaitu salah satunya dengan cara merevisi undang-undang nomor 31 tahun 2004 menjadi Undang- 


\section{$\mathcal{H}$ urnal Negara dan Keadilan \\ p-ISSN 2302-7010 e-ISSN 2721-9801}

undang Nomor 45 Tahun 2009 Tentang Perikanan. Hal ini mengingat kekayaan alam laut indonesia perlu dijaga, dilindungi dan dilestarikan bersama sama.

Dalam dasar pertimbangan UU itu disebutkan, bahwa perairan yang berada dalam kedaulatan Negara Kesatuan Republik Indonesia dan Zona Ekonomi Eksklusif Indonesia serta laut lepas mengandung sumber daya ikan yang potensial dan sebagai lahan pembudidayaan ikan merupakan berkah dari Tuhan Yang Maha Esa yang diamanatkan kepada bangsa Indonesia yang memiliki falsafah hidup Pancasila dan UUD Negara Republik Indonesia Tahun 1945, dengan memperhatikan daya dukung yang ada dan kelestariannya agar seyogyanya dapat dimanfaatkan sebesar-besarnya bagi kesejahteraan dan kemakmuran rakyat Indonesia. ${ }^{1}$

Berbagai bentuk kasus-kasus kriminalitas merupakan fenomena sosial yang terjadi di muka bumi ini, dan mungkin tidak akan ada habis-habisnya, hal ini akan jelas mengganggu terwujudnya keamanan dan ketertiban masyarakat. Sehingga seringkali kita mendengar maupun melihat baik melalui media cetak maupun elektronik maraknya aksi-aksi kejahatan yang dilakukan oleh pelaku tindak pidana. seperti: Pencurian baik yang dilakukan dengan kekerasan maupun dengan pemberatan, pembunuhan, perampokan dan jenis tindak pidana lainnya, belum lagi masih adanya penyakit masyarakat yang semakin meresahkan sampai saat ini.

Kondisi tersebut tentunya menimbulkan kekhawatiran tersendiri terhadap warga masyarakat dan institusi kepolisian selaku penegak hukum yang berdiri di garda terdepan dalam penegakan hukum. Masyarakat dihadapkan pada suatu perilaku seseorang atau sekelompok orang yang jelas-jelas bisa membahayakan nyawanya.

Kejahatan atau tindak pidana di tengah masyarakat dari waktu ke waktu semakin meningkat dan bermacam-macam. Ada tindak pidana yang hanya merugikan secara langsung pada korban secara individual, namun ada pula jenis tindak pidana yang merugikan masyarakat dan bangsa baik jangka pendek maupun jangka panjang. ${ }^{2}$ Salah satu jenis kejahatan yang belakangan ini sering terjadi dan mengundang banyak perdebatan di kalangan teoritisi maupun praktisi adalah masalah tindak pidana yang merugikan sumber daya laut, yang salah satunya adalah ikan.

Sampai kini problem illegal fishing di perairan Indonesia sulit diberantas, sekalipun pemerintah sudah menyediakan anggaran pengawasan sebesar Rp 271 miliar tahun 2008. Terbukti, baru-baru ini di perairan Tual, Maluku Tenggara, aparat keamanan kembali menangkap 7 kapal ikan Thailand. Pemerintah telah mengeluarkan Undang-Undang Perikanan No 31 Tahun 2004 dan Peraturan Menteri (Permen) No 17 Tahun 2006 yang mengatur ketentuan mata jaring alat tangkap di perairan Indonesia. Akan tetapi aktivitas illegal fishing tetap saja berlangsung. Ada apa di balik semua itu? Pencurian ikan di perairan Indonesia sudah berlangsung sejak tahun 1970-an. Akibatnya sembilan daerah wilayah

\footnotetext{
${ }^{1}$ Andi Salman, Kejahatan Elit di Indonesia, LPPKIS, Jakarta, 2008, hlm. 15.

${ }^{2}$ Ibid,
} 


\section{Hurnal Negara dan $\mathcal{X}$ eadilan \\ p-ISSN 2302-7010 e-ISSN 2721-9801}

pengelolaan perikanan (WPP) Indonesia, yaitu perairan Selat Malaka, Laut Cina Selatan, Laut Jawa, Selat Makasar dan Laut Flores, Laut Banda, Laut Seram sampai Teluk Tomini, Laut Sulawesi sampai Samudera Pasifik, Laut Arafura, dan Samudera Hindia, mengalami tingkat penangkapan lebih (over exploitation).

Terkecuali, di perairan Samudera Hindia, dan Laut Sulawesi sampai Samudera Pasifik. Sampai kini daerah yang masih marak pencurian adalah Laut Arafura, Laut Cina Selatan, Laut Sulawesi, perairan Selat Malaka, dan Samudera Hindia Disebutkan dalam salah satu dasar pertimbangan Undang-Undang Republik Indonesia Nomor 31 Tahun 2004 Tentang Perikanan bahwa perairan yang berada di bawah kedaulatan dan yurisdiksi Negara Kesatuan Republik Indonesia dan Zona Ekonomi Eksklusif Indonesia serta laut lepas berdasarkan ketentuan internasional, mengandung sumber daya ikan dan lahan pembudidayaan ikan yang potensial, merupakan berkah dari Tuhan Yang Maha Esa yang diamanahkan pada Bangsa Indonesia yang memiliki Falsafah Hidup Pancasila dan Undang-Undang Dasar 1945, untuk dimanfaatkan sebesar-besarnya bagi kesejahteraan dan kemakmuran rakyat Indonesia. ${ }^{3}$

Dasar pertimbangan itu sebenarnya mengingatkan manusia di dunia, bukan semata-mata Indonesia tentang karunia Tuhan dalam bentuk kekayaan laut yang tergolong istimewa. Tuhan memberikan modal kepada manusia berupa sumberdaya laut yang secara ekonomi bernilai tinggi. Di dalam laut, banyak tersedia berjenis-jenis kekayaan yang dibutuhkan manusia, khususnya sumber daya ikan.

Begitu banyaknya karunia Tuhan yang disimpan di laut dan dipercayakan kepada manusia untuk mengelolanya, sehingga membuat manusia banyak tergantung dengan pencarian kekayaan secara terus menerus dari laut. Salah satu kekayaan yang disimpan di laut dan menjadi kebutuhan utama manusia adalah ikan.

Sayangnya, seringkali manusia terjebak dalam pencarian dan eksploitasi kekayaan laut secara berlebihan atau tidak benar, melanggar kesepakatan, dan melanggar hukum sehingga menimbulkan problem sosial-ekologis yang tidak ringan. Ada hak-hak sesama pengguna atau pemanfaat laut seperti nelayan yang dirugikan, sementara ada hak-hak perlindungan keselamatan dan kelestarian ekologi laut yang menjadi korban atau mengalami kerusakan. Kasus pencurian ikan yang dilakukan oleh nelayan dalam negeri maupun asing merupakan bagian dari cara ilegal yang bisa merugikan negara maupun anggota masyarakat lain.

Dalam dasar pertimbangan huruf (b) Undang-Undang Republik Indonesia Nomor 31 Tahun 2004 Tentang Perikanan ditegaskan, bahwa dalam rangka pelaksanaan pembangunan nasional berdasarkan Wawasan Nusantara, pengelolaan sumber daya ikan perlu dilakukan sebaik-baiknya berdasarkan keadilan dan pemerataan dalam pemanfaatannya dengan mengutamakan perluasan kesempatan kerja dan peningkatan taraf hidup bagi nelayan, pembudi daya ikan, dan/atau pihakpihak yang terkait dengan kegiatan perikanan, serta terbinanya kelestarian sumber daya ikan dan lingkungannya.

\footnotetext{
${ }^{3}$ Muhammad Karim, Anatomi Konflik Nelayan, 2008, diakses tanggal 15 Juni 2019.
} 


\section{$\mathcal{H}$ urnal Negara dan Keadilan \\ p-ISSN 2302-7010 e-ISSN 2721-9801}

Meskipun sudah berkali-kali masyarakat diingatkan atau diberi informasi dan penekanan mengenai urgensinya perlindungan sumberdaya laut dan resoponsi terhadap hak-hak kehidupan dan kesejahteraan sesama, namun problem yang bersumber atau berhubungan dengan sumberdaya laut masih juga terjadi di masyarakat. Kekayaan laut telah menjadi bagian dari problem kriminalitas seperti konflik nelayan yang seringkali terjadi dan masalah pencurian ikan yang semakin merajalela. ${ }^{4}$

Ruddle (1999) telah mencatat batasan teritorial (territorial boundary) sebagai ciri dari pengelolaan sumber daya yang berbasis pada masyarakat, bahwa dari dulu hingga sekarang secara de facto nelayan pesisir menguasai suatu wilayah perairan tertentu, dan membatasi hak akses (access right) pada nelayan luar. Hal ini merupakan konsekuensi ciri kepemilikan sumberdaya laut yang bersifat common property atau milik bersama. Institusi kepemilikan tersebut sangat kuat pada tingkat komunitas, sehingga sangat dihargai nelayan manapun. Kondisi demikian bukan tidak menutup kemungkinan menjadi salah satu bagian dari akar masalah konflik nelayan.

Selain itu, perairan laut Indonesia yang luas menjadi habitat bagi pertumbuhan populasi ikan. Potensi maksimum perikanan laut Indonesia berkisar antara 6,7 sampai 7,7 metrik ton. Terumbu karang dengan 70 genus yang ada merupakan wujud keanekaragaman koral terbesar di dunia(Choi \& Hutagalung, 1998).

Dalam penjelasan Undang-Undang Republik Indonesia Nomor 31 Tahun 2004 Tentang Perikanan disebutkan, bahwa Negara Kesatuan Republik Indonesia sebagaimana dimaksud dalam Undang-Undang Dasar Negara Republik Indonesia Tahun 1945 memiliki kedaulatan dan yurisdiksi atas wilayah perairan Indonesia, serta kewenangan dalam rangka menetapkan ketentuan tentang pemanfaatan sumber daya ikan, baik untuk kegiatan penangkapan maupun pembudidayaan ikan sekaligus meningkatkan kemakmuran dan keadilan guna pemanfaatan yang sebesar-besarnya bagi kepentingan bangsa dan negara dengan tetap memperhatikan prinsip kelestarian sumber daya ikan dan lingkungannya serta kesinambungan pembangunan perikanan nasional.

Memang seharusnya setiap pihak yang terlibat dalam pemanfaatan sumberdaya laut seperti dalam kegiatan penangkapan ikan, tidaklah semata-mata kekayaan atau pendapatan berupa hasil tangakapan ikan saja yang menjadi dasar perhitungan, tetapi kepentingan sesama nelayan dan ekologis juga mendapatkan perhatian utama.

Tindak pidana pencurian ikan, apalagi yang dilakukan secara berkelompok dan menggunakan peralatan canggih dan bahan-bahan berbahaya, jelas-jelas dapat merugikan kehidupan bangsa Indonesia. Kejahatan atau tindak pidana tersebut dapat menghancurkan Indonesia, khususnya sumberdaya laut baik jangka pendek maupun janga panjang, karenanya agar kejahatan di atas tidak terus terjadi perlu dilakukan langkah-langkah tegas baik dari sisi pemidanaan terhadap pelaku maupun dari sisi pengamanan terhadap eksositem laut.

\footnotetext{
${ }^{4}$ Fadoli Ahmad, 2006, diakses tanggal 15 Juni 2019
} 


\section{Hurnal Negara dan $\mathcal{X}$ eadilan \\ p-ISSN 2302-7010 e-ISSN 2721-9801}

\section{METODE PENELITIAN}

Pada penelitian ini menggunakan jenis penelitian bersifat yuridis normatif atau meneliti tentang norma peraturan perundang-undangan. Penelitian ini juga bersifat deskriptif karena dimaksudkan untuk memberikan data iyang seteliti mungkin tentang manusia, keadaan atau gejala-gejalanya. Adapun penelitian hukum ini menggunakan pendekatan perundang-undangan. Peneliti juga menggunakan pendekatan konsesional yang mengkaji konsep-konsep atau ide-ide tentang hukum yang disampaikan oleh para ahli atau pakar.

\section{PEMBAHASAN}

\section{Illegal Fishing dalam Perspektif Hukum Pidana Indonesia}

Beberapa norma yuridis yang berkaitan dengan pengaturan sanksi bagi siapapun yang melakukan tindak pidana penangkapan ikan secara ilagal atau illegal fishing. Para Pelaku pelanggaran illegal fishing di perairan ZEEI bagi kapal asing dikenakan sanksi denda yang lebih besar dan pantas sehingga tidak menimbulkan kerugian besar bagi Negara pantai, serta akan memberikan efek jera bagi pelaku pelanggaran illegal fishing terhadap kapal asing. Sedangkan pelanggaran illegal fishing oleh Negara pantai dikenakan sangsi hukuman yang berlaku di Negara tersebut. Negara pantai hanya dapat melaksanakan pengolahan dan pemanfaatan sumber daya alam hayati di wilayah perairan ekslusif Indonesia dan hanya dapat melakukan proses penahanan sampai ke tingkat pengadilan sesuai perjanjian hukum laut Internasional dan tidak diperboleh melaksanakan hukuman penjara, asalkan ada kerja sama dan kesepakatan antar Negara tersebut. ${ }^{5}$ Serta segera menginformasikan sanksi yang diberikan pada pelaku pelanggaran illegal fishing kepada Negara yang melakukan tindak Pidana. ${ }^{6}$ Dalam pelangaran tindak pidana perikanan oleh kapal asing di ZEEI, yang telah di tahan oleh Negara pantai secepat mungkin di bebaskan dengan ganti rugi yang pantas yang di terima oleh Negara pantai. Penahanan tidak diijinkan dalam bentuk kurungan penjara. Untuk mendukung penegakkan hukum tindak pidana Illegal Fishing yang terjadi di negara Indonesia telah ditetapkan beberapa UU dan Peraturan Pemerintah, sehingga payung hukum yang digunakan menjadi semakin kuat.

Dalam kerangka berfikir idealistis, menurut Satjipto Rahardjo, ${ }^{7}$ bahwa norma hukum, termasuk hukum pidana adalah sarana yang dipakai oleh masyarakat untuk mengarahkan tingkah laku anggota masyaakat pada saat mereka berhubungan antara yang satu dengan lainnya. Apabila di sini disinggung tentang "mengarahkan tingkah laku", barang tentu pertanyaan dalam diri kita, "mengarahkan kemana"? ke mana norma itu mengarahkan tingkah laku manusia

\footnotetext{
${ }^{5}$ Chairul Anwar, Horizon Baru Hukum Laut Internasional, Rhineka Cipta, Jakarta, 1998, hlm.

${ }^{6}$ E Mantjoro Dan Potoh O, Internasional Fishier Policy (Kebijaksnaan Perikanan Internasional), Alumni, Bandung, 1993, hlm. 73

${ }^{7}$ Al-Hilal Hamdi, Menjelajah Dunia Hukum, LPP-Mpres, Jakarta, 2007, hal. 2
} 


\section{Jurnal Negara dan $\mathcal{X}$ eadilan \\ p-ISSN 2302-7010 e-ISSN 2721-9801}

merupakan prioritas yang ada pada masyarakat sendiri. Masyarakatlah yang menentukan arah-arah tersebut dan oleh karena itu kita bisa melihat norma itu sebagai pencerminan dari kehendak masyarakat. Kehendak masyarakat untuk mengarahkan tingkah laku anggota-anggota masyarakat itu dilakukan dengan membuat pilihan antara tingkah laku yang disetujui dan yang tidak disetjui yang kemudian merupakan norma dalam masyarakat itu. Oleh karena itu, norma hukum itu merupakan persyaratan dari penilaian-penilaian.

Indonesia hingga kini masih menjadi sasaran penangkapan ikan ilegal. Hal itu terbukti dari masih banyaknya kasus penangkapan ikan ilegal di perairan oleh nelayan asing. Sebagian besar kasus pidana perikanan berlangsung di perairan perbatasan dengan negara tetangga.

Ada beberapa kategori pada nelayan/kapal berbendera Indonesia yang disebut melakukan tindakan illegal fishing, yaitu :

1. kapal penangkap ikan dalam pengoperasiannya tidak dilengkapi dengan Surat Izin Penangkapan Ikan (SIPI)

2. kapal pengangkut ikan dalam pengoperasiannya tidak dilengkapi dengan Surat Izin Kapal Pengangkutan Ikan (SIKPI);

3. jalur dan daerah penangkapan tidak sesuai dengan yang tertera dalam izin;

4. penggunaan bahan atau alat penangkapan ikan berbahaya atau alat penangkapan ikan yang dilarang;

5. pemalsuan surat izin penangkapan ikan;

6. manipulasi dokumen kapal, antara lain ukuran, lokasi pembuatan, dan dokumen

kepemilikan kapal;

7. nama kapal, ukuran kapal dan/atau merek, nomor seri, dan daya mesin tidak sesuai dengan yang tercantum dalam izin;

8. jenis, ukuran dan jumlah alat tangkap dan/atau alat bantu penangkapan tidak sesuai dengan yang tercantum dalam izin;

9. kapal beroperasi tanpa Surat Persetujuan Berlayar (SPB);

10. tidak memasang atau tidak mengaktifkan alat pemantauan kapal penangkap ikan

dan kapal pengangkut ikan yang ditentukan (antara lain transmitter VMS);

11. kapal penangkap ikan dan kapal pengangkut ikan melakukan bongkar muat di tengah laut tanpa izin;

12. kapal penangkap ikan mengangkut hasil tangkapan langsung ke luar negeri tanpa

melapor di pelabuhan yang ditentukan

13. kapal penangkap ikan dan kapal pengangkut ikan berbendera Indonesia menangkap/mengangkut ikan di wilayah yurisdiksi negara lain tanpa izin dari negara yang bersangkutan dan tanpa persetujuan dari Pemerintah Republik Indonesia

Salah satu bentuk penegakan hukum terhadap tindak pidana illegal fishing adalah melakukan tindakan terhadap kapal-kapal yang melakukan pencurian atau memasuki kawasan Indonesaia secara melawan hukum, yang masuknya ini diduga atau tterbukti melakukan illegal fishing. 


\section{Zurnal Negara dan $\mathcal{X}$ eadilan \\ p-ISSN 2302-7010 e-ISSN 2721-9801}

Kapal-kapal asing penangkap ikan yang beroperasi secara ilegal di perairan Indonesia, harus mulai waspada dan lebih hati-hati. Jika ketahuan melakukan pelanggaran, selain kena tindak pidana, juga harus membayar denda Rp 2 miliar. Kerugian Indonesia akibat ulah pencurian ikan oleh kapal-kapal asing setiap tahunnya tidak kurang dari dua miliar dolas AS. Sebagai contoh kasus, Praktik penangkapan ikan secara ilegal di wilayah perairan Maluku paling banyak terjadi di Laut Arafura. Maraknya pencurian ikan di daerah tersebut disebabkan oleh luasnya wilayah perairan serta terbatasnya sarana dan prasarana pengawasan yang dimiliki pemerintah pusat maupun pemerintah daerah, serta TNI Angkatan Laut maupun Polisi Perairan.

Menurut ahli sosiologi hukum dari Amerika Serikat (Lawrence M. Friedman, 1969, dalam Umar Said, Dinamika Hukum, 2004) disebutkan, bahwa ada tiga faktor yang mempengaruhi penegakan hukum, yakni: Pertama, faktor struktural. Faktor struktural dalam pelaksanaan penegakan hukum adalah lembaga hukum yang diciptakan oleh negara berdasarkan Undang-Undang. Lembaga hukum ini antara lain: lembaga peradilan, kejaksaan, dan Kepolisian. Selain itu masih ada lembaga pelaksana hukum lainnya dibidang administratif/ birokrasi, misalnya Badan Pertanahan, Catatan Sipil, Perpajakan dan lain sebagainya.Penegakan hukum oleh lembaga struktural ini tergantung pada kemampuan, kejujuran (moral), keberanian dan kemauan bekerja keras secara profesional manusia-manusia yang ada di lembaga ini.

Kedua, faktor substantip. Faktor ini merupakan faktor output dari system hukum,artinya norma-norma hukum yang dipergunakan untuk mengatur tingkah laku manusia serta hak dan kewajiban manusia, mengatur pihak yang menegakkan hukum maupun pihak yang diatur/terkena peraturan. Norma hukum di sini bisa berbentuk tertulis (peraturan perundang-undangan) maupun tidak tertulis (hukum adat atau kebiasaan). Keberadaan hukum tertulis (peraturan perundang-undangan) ini tergantung pula terhadap kualitas para pembuatnya.

Ketiga, faktor kultural. Faktor kultural merupakan nilai-nilai moral dan budaya atau sikap masyarakat dapat mempengaruhi penegakan hukum. Nilai-nilai positif dari masyarakat dapat mendukung keberhasilan penegakan hukum, tetapi sebalinya penegakan hukum akan gagal apabila dipengaruhi unsur nilai-nilai negatif yang ada di masyarakat (misal suka mencari jalan pintas lebih baik menyuap petugas daripada sidang ke pengadilan).

Dalam Pasal 84 UU Nomor 32 Tahun 2004 tentang Perikanan juga digariskan (1) Setiap orang yang dengan sengaja di wilayah pengelolaan perikanan Republik Indonesia melakukan penangkapan ikan dan/atau pembudidayaan ikan dengan menggunakan bahan kimia, bahan biologis, bahan peledak, alat dan/atau cara, atau bangunan yang dapat merugikan atau membahayakan kelestarian sumber daya ikan dan/atau lingkungannya sebagaimana dimaksud dalam Pasal 8 ayat (1), dipidana dengan pidana penjara paling lama 6 (enam) tahun dan denda paling banyak Rp1.200.000.000, (satu miliar dua ratus juta rupiah).

Dari aspek yuridis, masalah tindak pidana pencurian ikan memang bisa dijerat oleh KUHP maupun UU Perikanan (UU 31 Tahun 2004). Namun untuk 


\section{Jurnal Negara dan $\mathcal{X}$ eadilan \\ p-ISSN 2302-7010 e-ISSN 2721-9801}

pencurian ikan di laut, aparat penegak hukum menggunakan UU Perikanan, sedangkan untuk pencurian ikan di luar wilayah kawasan laut, digunakan KUHP yang mengatur pasalpasal pencurian. Penggunaan dasar yuridis ini dikaitkan dengan obyek yang menjadi korban tindak pidana pencurian ikan. Penggunaan dasar yuridis ini menjadi kompetensi aparat penegak hukum. Hukum akan menjadi sarana yang bermanfaat bagi kepentingan dunia hukum maupun khususnya kepentingan masyarakat dan bangsa jika dilaksanakan dengan sebaikbaiknya.

\section{Tindak Pidana Illegal Fishing dalam Perspektif Kriminologi Indonesia}

Dari aspek kriminologis, ada tiga hal yang bisa digunakan sebagai kajiannya, yakni aspek modus operandi, faktor penyebab, dan akibat-akibat tindak pidana dari pencurian ikan yaitu sebagai berikut:

\section{Modus operandi tindak pidana penangkapan (pencurian) Ikan di Indonesia}

Tindak pidana penangkapan ikan secara ilegal atau Tindakan illegal fishing pada umumnya terjadi di seluruh wilayah perairan di dunia, termasuk di Negara Indonesia. Negara Indonesia yang merupakan negara maritim juga tidak lepas dari masalah pidana penangkapan ikan secara ilegal atau illegal fishing. Tindakan kejahatan yang terjadi di wilayah perairan ini menjadi tindakan yang sudah terorganisir di tingkat nasional hingga internasional. Pencurian ikan merupakan salah satu musuh bersama bangsa-bangsa di dunia. Betapa tidak, selain menguras ketersediaan sumber daya ikan, juga menggerogoti pendapatan negara. Banyak deklarasi regional dan internasional dipublikasikan untuk meneguhkan komitmen memerangi praktek pencurian ikan. Tindakan illegal fishing ini menjadi perhatian organisasi dunia, seperti Food and Agriculture Organization yang juga ikut dalam mengatur kasus ini. FAO mengamati kasus illegal fishing dengan melihat aspek keberlangsungan ekosistem dan sumber daya perikanan yang terkandung didalamnya. Selain itu terdapat juga aspek ekonomi yang menjadi perhatian dalam tindakan Illegal Fishing.

Satu hal yang harus kita paham, bahwa banyaknya tindakan pidana penangkapan ikan secara ilegal atau illegal fishing yang terjadi dalam wilayah perairan Indonesia disebabkan oleh beberapa hal. Rata-rata para pelaku illegal fishing tidak memiliki surat izin untuk menangkap ikan. Para nelayan banyak yang tidak memiliki surat-surat atau dokumen lengkap. Selain itu, penggunaan bahan kimia dan alat tangkap yang terlarang telah menjadi hal yang biasa bagi para nelayan khususnya nelayan tradisional. Bagi para nelayan, jika menggunakan alat pancing seadanya hasil yang diperoleh sedikit dan hanya mendapat keuntungan kecil. Banyak pelanggaran yang dianggap menjadi tindakan illegal fishing.

Modus operandi tindak pidana illegal fishing, bukan hanya dilakukan secara individual, tetapi juga secara berkelompok. Kalau modus operandi pencurian ikannya di wilayah laut, maka wilayah laut yang dimasukinnya ini bisa berupa wilayah tangkapan orang atau daerah lain, wilayah perikanan orang lain (seperti tambak atau kolam ikan), atau negara lain. 


\section{Faktor-faktor Penyebab dan Akibat yang ditimbulkan oleh Tindak Pidana Pencurian Ikan di Indonesia}

Kolusi antara antara pejabat dengan pemilik atau pengusaha kapal telah berpengaruh terhadap semakin merajalelanya pencurian ikan atau menjadi penyebab utama terhadap terjadinya pencurian ikan, di samping faktor kemiskinan, dan perdebatan soal wilayah tangkapan ikan, yang dianggap masih menjadi daerah yang dibenarkan untuk beroperasi.

Dijelaskan oleh Muhammad Karim, bahwa apabila dicermati penyebabnya, pertama, perizinan yang tidak beres. Illegal fishing terjadi karena (i) pemalsuan perizinan, (ii) duplikasi perizinan dan (iii) tanpa adanya perizinan. Kedua, konspirasi bisnis tingkat tinggi antara pengusaha domestik, pegusaha kapal asing, birokrasi dan oknum-oknum yang dekat elit penguasa. Mereka mempunyai kekuatan akses politik dan jaringan "kekuasaan" yang sulit disentuh aparat keamanan sekalipun. Ada "komprador" yang membeking pelaku kejahatan ini dengan perlindungan dan kelancaran pengeluaran izin.

Ketiga aspek tersebut menunjukkan, bahwa Kalau modus operandi illegal fishing di wilayah laut, maka wilayah laut yang dimasukinnya ini bisa berupa wilayah tangkapan orang atau daerah lain, wilayah perikanan orang lain (seperti tambak atau kolam ikan), atau negara lain. Nelayan dari negara lain dengan menggunakan sarana berupa kapal laut memasuki wilayah laut Indonesia untuk menangkap ikan. Sedangkan dari segi dampak atau akibat tindak pidana illegal fishing di wilayah perairan Indonesia ini memang sudah pada tahap yang sangat memprihatinkan. Selain telah merugikan negara triliunan rupiah per tahun.

Dari sisi faktor penyebabnya diantaranya adalah: tindakan hukum terhadap pelaku masih lemah, seperti masih diberikannya izin penangkapan bagi awak kapal yang kasusnya telah disidangkan di pengadilan keterbatasan kemampuan pengawasan dan pengendalian, baik oleh aparat pusat dan daerah maupun oleh Tentara Nasional Indonesia (TNI) Angkatan Laut dan Polisi Perairan, serta luasnya wilayah perairan laut Indonesia, di samping keterbatasan pengawasan telah membuat illegal fishing yang dilakukan oleh nelayan atau kapal-kapal asing merajalela. Faktor ini masih ditambah faktor lain seperti kondisi sebagian masyarakat yang sedng ditimpa suatu kemiskinan, yang terpaksa melakukan tindak pidana illegal fishing untuk memenuhi kebutuhan dalam kehidupan sehari-hari

\section{Perbandingan antara Perspektif Hukum Pidana terhadap Tindak Pidana Illegal Fishing di Indonesia dengan Perspektif Kriminologi terhadap Tindak Pidana Illegal Fishing di Indonesia}

Dalam kajian hukum pidana disebutkan, bahwa masalah kejahatan tindak pidana pencurian ikan atau dikenal dengan illegal fishing memang bisa dijerat oleh KUHP maupun Undang-Undang Perikanan yaitu UU 31 Tahun 2004 sebagaimana telah diubah dengan Undang-undang Nomor 45 Tahun 2009 tentang Perikanan). Namun untuk pencurian ikan di laut, aparat penegak hukum 


\section{Zurnal Negara dan $\mathcal{X}$ eadilan \\ p-ISSN 2302-7010 e-ISSN 2721-9801}

menggunakan UU Perikanan, sedangkan untuk pencurian ikan di luar wilayah kawasan laut, digunakan KUHP yang mengatur tentang pasal-pasal tindak pidana pencurian yang terjadi diluar kewenangan sebagaimana di atur dalam Undangundang Tenteng Perikanan.

Penggunaan dasar yuridis tersebut dikaitkan dengan obyek yang menjadi korban tindak pidana pencurian ikan. Penggunaan dasar yuridis ini menjadi kompetensi aparat penegak hukum. Hukum akan menjadi sarana yang bermanfaat bagi kepentingan dunia hukum maupun khususnya kepentingan masyarakar dan bangsa jika dilaksanakan dengan sebaik-baiknya.

Tindak pidana illegal fishing dari kajian kriminologi diantaranya dibahas dari aspek modus operandi dan dampak serta faktor penyebab tindak pidana pencurian ikan, Dari segi modus operandi tindak pidana illegal fishing bukan hanya dilakukan secara individual, tetapi juga secara berkelompok.

Kalau modus operandi tindak pidana illegal fishing di wilayah laut, maka wilayah laut yang dimasukinnya ini bisa berupa wilayah tangkapan orang atau daerah lain, wilayah perikanan orang lain (seperti tambak atau kolam ikan), atau negara lain. Nelayan dari negara lain dengan menggunakan sarana berupa kapal laut memasuki wilayah laut Indonesia untuk menangkap ikan. Sedangkan dari segi dampak atau akibat tindak pidana pencurian ikan di wilayah perairan Indonesia ini memang sudah pada tahap yang sangat memprihatinkan. Selain telah merugikan negara triliunan rupiah per tahun.

Kalau ditelaah dari sisi penyebabnya diantaranya: tindakan hukum terhadap pelaku masih lemah, seperti masih diberikannya izin penangkapan bagi awak kapal yang kasusnya telah disidangkan di pengadilan keterbatasan kemampuan pengawasan dan pengendalian, baik oleh aparat pusat dan daerah maupun oleh TNI Angkatan Laut dan Polisi Perairan, serta luasnya wilayah perairan laut Indonesia, di samping keterbatasan pengawasan telah membuat illegal fishing yang dilakukan oleh nelayan atau kapal-kapal asing merajalela Jika didasarkan hal itu, maka perbandingan antara perspektif hukum pidana terhadap tindak pidana penangkapan ikan secara ilegal atau illegal fishing di Indonesia dengan perspektif ilmu kriminologi terhadap tindak pidana pencurian ikan atau yang dikenal dengan istilah illegal fishing di Indonesia menunjukkan, bahwa dari aspek hukum pidana sudah diatur atau ada ketentuan yang menyebutkan (menggariskan), bahwa apa yang dilakukan oleh para pelaku illegal fishing dapat dituntut atau dimintai sebuah pertanggungjawaban pidana atau hukum sesuai dengan ketentuan peraturan perundang-undangan yang berlaku baik dalam ketentuan Undang-undang tenteng Perikanan atau dalam ketentuan KUHP yang terkait dengan tindak pidana yang pengaturannya tidak terdapat dalam undangundang tentang Perikanan, yang diantaranya dengan sanksi yang sudah dirumuskannya, sedangkan dari aspek kriminologis sudah dijelaskan, bahwa ada banyak modus operandi terhadap illegal fishing, di samping faktor penyebab atau yang melatarbelakangi terjadinya praktik illegal fishing di Indonesia ini. 


\section{$\mathcal{H}$ urnal Negara dan $\mathcal{X}$ eadilan \\ p-ISSN 2302-7010 e-ISSN 2721-9801}

\section{PENUTUP}

Perspektif hukum pidana terhadap tindak pidana illegal fishing di Indonesia menunjukkan, bahwa masalah kejahatan atau tindak pidana penangkapan ikan secara ilegal atau dikenal dengan illegal fishing memang bisa dijerat oleh KUHP maupun UU Perikanan UU 31 Tahun 2004 tentang Perikanan). Namun untuk pencurian ikan di laut, aparat penegak hukum menggunakan UU Perikanan, sedangkan untuk pencurian ikan di luar wilayah kawasan laut, digunakan KUHP yang mengatur pasal-pasal tindak pidana pencurian. Penggunaan dasar yuridis ini dikaitkan dengan obyek yang menjadi korban tindak pidana pencurian ikan. Penggunaan dasar yuridis ini menjadi kompetensi aparat penegak hukum. Hukum akan menjadi sarana yang bermanfaat bagi kepentingan masyarakat secara umum dan sebagai sarana sosial atau kontrol sosial untuk mencegah terjadinya suatu tindak pidana baik tindak pidana secara umum atau dalam hal ini tindak pidan pencurian ikan.

Dalam Perspektif kriminologi terhadap tindak pidana illegal fishing di Indonesia menunjukkan diantaranya adalah dari aspek modus operandi dan dampak serta faktor penyebab tindak pidana pencurian ikan, Dari segi modus operandi tindak pidana illegal fishing bukan hanya dilakukan secara individual, tetapi juga secara berkelompok. Kalau modus operandi Illegal fishing di wilayah laut, maka wilayah laut yang dimasukinnya ini bisa berupa wilayah tangkapan orang atau daerah lain, wilayah perikanan orang lain (seperti tambak atau kolam ikan), atau Negara lain. Nelayan dari negara lain dengan menggunakan sarana berupa kapal laut memasuki wilayah laut Indonesia untuk menangkap ikan. Sedangkan dari segi dampak atau akibat tindak pidana pencurian ikan di wilayah perairan Indonesia ini memang sudah berada pada tahap yang sangat memprihatinkan. Selain telah merugikan negara triliunan rupiah per tahun. Dari sisi Penyebabnya diantaranya: tindakan hukum terhadap pelaku masih lemah, seperti masih diberikannya izin penangkapan bagi awak kapal yang kasusnya telah disidangkan di pengadilan keterbatasan kemampuan pengawasan dan pengendalian, baik oleh aparat pusat dan daerah maupun oleh TNI Angkatan Laut dan Polisi Perairan, serta luasnya wilayah perairan laut Indonesia, di samping keterbatasan pengawasan telah membuat illegal fishing yang dilakukan oleh nelayan atau kapal-kapal asing merajalela.

Perbandingan antara perspektif hukum pidana terhadap tindak pidana penangkapan ikan secara ilegal atau illegal fishing di Indonesia dengan perspektif kriminologi terhadap tindak pidana illegal fishing di Indonesia menunjukkan, bahwa dari aspek hukum pidana sudah diatur atau ada ketentuan yang menyebutkan bahwa apa yang dilakukan oleh para pelaku illegal fishing dapat dituntut atau dimintai pertanggungjawaban pidana atau hukum, yang diantaranya dengan sanksi yang sudah dirumuskannya, sedangkan dari aspek kriminologis sudah dijelaskan, bahwa ada banyak modus operandi terhadap illegal fishing, di samping faktor penyebab atau yang melatarbelakangi terjadinya praktik illegal fishing di Indonesia ini. 


\section{Jurnal Negara dan $\mathcal{X}$ eadilan \\ p-ISSN 2302-7010 e-ISSN 2721-9801}

\section{DAFTAR PUSTAKA}

\section{Peraturan Perundang-undangan}

Undang-undang Dasar Negara Republik Indonesia Tahun 1945

Kitab Undang-undang Hukum Pidana (KUHP)

Undang-undang Nomor 31 Tahun 2004 Tentang Perikanan

Undang-undang Nomor 45 Tahun 2009 Tentang Perikanan

\section{Buku}

Andi Salman, Kejahatan Elit di Indonesia, LPPKIS, Jakarta, 2008,

Abdul wahid, Kriminologi dan Kejahatan Kontemporer, Visipress, Surabaya, 2003.

Badruttamam, Pembalakan Ikan di Indonesia, Lentera, Yogyakarta, 2015.

Barda Nawawi Arief. Bunga Rampai Kebijakan Hukum Pidana. PT. Citra Aditya

Bakti, Bandung, 1996. Frans E. Likadja, Bunga Rampai Hukum Laut Internasional, Bina Cipta, Bandung, 1998

I Njoman Nurjaya, Dinamika Hukum, Edisi September 2002, Fakultas Hukum Universitas Islam Malang

Kansil, CST. Pengantar Ilmu Hukum dan Tata Hukum Indonesia, Balai Pustaka, Jakarta, 2000.

Moh. Muhibbin, Abdul Wahid, Hukum Kewarisan Islam Sebagai Pembaharuan Hukum Positif di Indonesia, Sinar Grafika, Jakarta, 2011.

M. Sudrajat Bassar, Tindak-tindak Pidana Tertentu dalam KUHP. Remadja Karya. CV. Bandung, 1986.

Moeljatno, Asas-asas Hukum Pidana. PT. Rineka Cipta Jakarta, 1993..

Satjipto Rahardjo, 1991, Ilmu Hukum, Bandung: Citra Aditya Media.

Soerjono Soekanto, 1989, Faktor-faktor yang Mempengaruhi Penegakan Hukum, Jakarta: Rajawali Pres.

Soerjono Soekanto \& Sri Mamudji, Penelitian Hukum Normatf, Rajagrafindo Persada, Jakarta, 2003

Umar Said, Penegakan Hukum, Jurnal Dinamika Hukum, 2004.

Internet

Arif Satria, Otonomi Daerah dan Konflik Nelayan, Republika, 12 Agustus 2003, akses 15 Juni 2020.

Kompas, 16 januari 2004, Tangkapan Berkurang, Konflik Nelayan Meningkat, akses 15 Juni 2020

Kompas, 15 Pebruari 2006, Konflik Nelayan Hambat Investasi, akses 15 Juni 2020

Kusnadi, Perlu Ada Perda untuk Atasi Konflik Nelayan di Jatim, Kompas, 13 Oktober 2003, akses 15 Juni 2020.

Muhammad Karim, "Problem Ekonomi-Politik Kemiskinan Nelayan", Sinar Harapan, 23 Agustus 2003, akses 15 Juni 2020

Muhammad Karim “Anatomi Konflik Nelayan”, Republika, 4 Oktober 2005, akses 15 Juni 2020

Muhibbin, Kearifan Menyikapi Konflik Nelayan, Surabayapost, 4 Oktober 2005, akses 15 Juni 2020.

Tempo-Interaktif, tanggal 29 Juli 2008, akses 15 Juni 2020. 